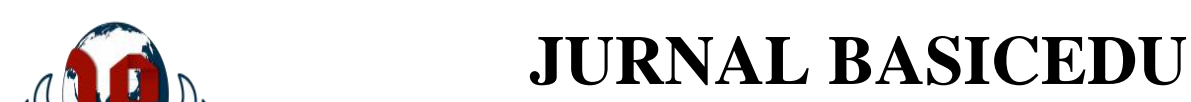

Volume 5 Nomor 4 Tahun 2021 Halaman 2440 - 2448

Research \& Learning in Elementary Education

https://jbasic.org/index.php/basicedu

PAHLAWAN

\title{
Pengembangan Media Pembelajaran Interaktif Berbasis Google Slide pada Materi Pecahan Sederhana di Sekolah Dasar
}

\author{
Syifa Jamilah Purnama ${ }^{\natural}$, Puri Pramudiani ${ }^{2}$ \\ Universitas Muhammadiyah Prof. DR. HAMKA, Indonesia ${ }^{12}$ \\ E-mail: syifajamilah248@ gmail.com¹, puri.pramudiani@uhamka.ac.id ${ }^{2}$
}

\begin{abstract}
Abstrak
Penelitian ini bertujuan untuk mengetahui kualitas dan kelayakan media pembelajaran interaktif berbasis Google Slide pada materi pecahan sederhana. Penelitian ini merupakan penelitian pengembangan dengan model ADDIE yang memiliki lima tahapan yaitu analisis, perancangan, pengembangan, penerapan dan evaluasi. Pengumpulan data dilakukan dengan cara observasi, wawancara dan kuesioner. Validasi media berdasarkan uji ahli materi dan ahli media. Sampel penelitian yaitu siswa kelas III SDS Muhammadiyah 4 Jakarta. Hasil uji ahli materi memperoleh skor 98\% dengan kategori sangat layak dan hasil uji media memperoleh skor $71,1 \%$ dengan kategori layak. Respon siswa terhadap media memperoleh hasil 93\% dengan kategori sangat baik. Dari penelitian ini dapat disimpulkan bahwa media pembelajaran interaktif berbasis Google Slide layak dan baik dalam melihat kualitas pemahaman konsep materi dan memotivasi siswa dalam pembelajaran tersebut.
\end{abstract}

Kata Kunci: Pengembangan, Media Pembelajaran Interaktif, Google Slide.

\begin{abstract}
This study aims to determine the quality and feasibility of interactive learning media based on Google Slides on simple fractions. This research is development research using the ADDIE model which has five stages, namely analysis, design, development, implementation, and evaluation. Data was collected by means of observation, interviews, and questionnaires. Media validation was based on material and media expert tests. The research sample was the third-grade students of SDS Muhammadiyah 4 Jakarta. The result of the material expert test obtained a score of $98 \%$ which means in a very feasible category and the media test obtained a score of $71.1 \%$ which means in an appropriate category. Student's responses to the media obtained 93\% results which means in the very good category. The conclusion of the research is that interactive learning media based on Google Slides is feasible and good to see the quality of understanding the material concepts and to motivate the students in the learning process.
\end{abstract}

Keywords: Development, Interactive Learning Media, Google Slide.

Copyright (c) 2021 Syifa Jamilah Purnama, Puri Pramudiani

Corresponding author :

Email : syifajamilah248@gmail.com

DOI $\quad$ : https://doi.org/10.31004/basicedu.v5i4.1247

ISSN 2580-3735 (Media Cetak)

ISSN 2580-1147 (Media Online)

Jurnal Basicedu Vol 5 No 4 Tahun 2021

p-ISSN 2580-3735 e-ISSN 2580-1147 
2441 Pengembangan Media Pembelajaran Interaktif Berbasis Google Slide pada Materi Pecahan Sederhana di Sekolah Dasar - Syifa Jamilah Purnama, Puri Pramudiani

DOI: https://doi.org/10.31004/basicedu.v5i4.1247

\section{PENDAHULUAN}

Kualitas pendidikan yang unggul dapat dilihat salah satunya dari pemanfaatan media pembelajaran yang digunakan oleh pendidik. Media disebut sebagai instrumen untuk menyampaikan informasi dari pengirim kepada penerima (Budiman, 2016). Media dapat dikatakan sebagai alat interaksi antara pendidik dengan peserta didik untuk memberikan informasi dan pengetahuan (Ihsana, 2017). Media terbagi menjadi enam yaitu visual, audio visual, kombinasi slide dan suara, komputer, komputer dan interaktif video, dan internet (Ihsana, 2017). Setiap bagian dari media tersebut mempunyai keunggulannya masing-masing sesuai dengan strategi dan tujuan pembelajaran karena dengan penggunaan media pembelajaran yang sesuai maka pendidik menjadi lebih mudah dalam menyampaikan materi dan membantu dalam memahami pelajaran.

Media pembelajaran memiliki fungsi sebagai alat komunikasi untuk mempermudah penyampaian pesan dari penyampai pesan kepada penerima pesandan juga dapat menumbuhkan motivasi siswa dalam belajar, meningkatkan rasa keingintahuan dan juga dapat menambah informasi (Dwijayani, 2019).

Media pembelajaran interaktif merupakan media digital yang saling terintegrasi untuk membantu guru berinteraksi dengan siswa yang mencangkup electronic text (teks elektronik), graphics (grafik), moving images (gambar bergerak) dan sound (suara). Dalam hal ini yang termasuk dalam konteks digital yaitu interactive digital television (televisi digital interaktif), internet, game interactive (permainan interaktif), dan telekomunikasi (Arindiono et al., 2013). Media ini sangat tepat digunakan pada situasi saat ini dimana sebagian besar proses pembelajaran dilakukan secara daring sebagai implementasi dari kebijakan pemerintah dalam rangka memutus rantai penularan virus COVID-19. Study from home (belajar di rumah) merupakan perubahan sistem pembelajaran peserta didik dari tatap muka menjadi daring atau e-learning (Setiawan et al., 2021). Belajar di rumah menimbulkan berbagai macam perubahan pada pembelajaran, baik kepada pendidik maupun peserta didik.

Salah satu pelajaran yang membutuhkan media agar peserta didik dapat memahami materi yang abstrak adalah matematika. Matematika adalah ilmu yang wajib dikuasai peserta didik karena matematika merupakan ratunya ilmu sehingga matematika diperlukan di berbagai ilmu lainnya (Rahmah, 2013). Namun banyak peserta didik yang mengalami kesulitan untuk menguasai konsep matematika apabila materi tersebut tidak di representasikan (Damayanti \& Qohar, 2019). Untuk merepresentasikannya membutuhkan perantara suatu media yang dapat mengartikan konsep yang abstrak kepada peserta didik. Salah satu materi yang memerlukan media adalah pecahan sederhana, karena konsep pecahan yang tertanam dengan baik akan memunculkan pemahaman yang kuat (Jannah et al., 2021).

Media interaktif berbasis multimedia atau website saat ini adalah salah satu pilihan yang digunakan pendidik karena dapat dilakukan secara daring akan tetapi tetap pada fungsinya yaitu menyampaikan pesan kepada peserta didik (Fitra \& Maksum, 2021). Saat ini banyak platform digital berupa website untuk memfasilitasi pembelajaran daring yang dapat dimanfaatkan oleh pendidik dan peserta didik. Salah satunya adalah Google Slide, yang pertama kali dikenalkan kepada publik pada tanggal 9 Maret 2006 sebagai google presentations. Google Slide saat ini memiliki keuntungan dapat melakukan presentasi dan tanya jawab secara daring dengan menggunakan laptop maupun smartphone (Anshori \& Syam, 2018).

Berdasarkan hasil analisis pendahuluan yang dilakukan melalui observasi dan wawancara kepada para pendidik di kelas III SDS Muhammadiyah 4 Jakarta, dapat diketahui jika mereka hanya menggunakan media buku dan unggahan video di Youtube sehingga sering mendapatkan keluhan dari para orang tua siswa dikarenakan penjelasan kurang detail yang menyebabkan siswa tidak memahami materi pelajaran. Keluhan para orang tua tersebut dikarenakan banyaknya platform pembelajaran yang digunakan sehingga orang tua kewalahan dalam membimbing anaknya terutama pada pelajaran matematika khususnya materi pecahan sederhana dimana siswa kurang memahami perbedaan letak penyebut dan pembilang. Media diperlukan bukan hanya untuk membantu siswa memahami konsep melainkan diperlukan media yang praktis dan efektif. 


\section{Pengembangan Media Pembelajaran Interaktif Berbasis Google Slide pada Materi Pecahan Sederhana}

di Sekolah Dasar - Syifa Jamilah Purnama, Puri Pramudiani

DOI: https://doi.org/10.31004/basicedu.v5i4.1247

Menurut Soenarto (2005) penelitian pengembangan memiliki batasan proses dalam mengembangkan dan memvalidasi produk yang akan digunakan untuk pendidikan dan pembelajaran. Penelitian pengembangan merupakan pengupayaan untuk mengembangkan dan menghasilkan suatu produk berupa media, alat, materi dan strategi pembelajaran yang berfungsi untuk mengatasi pembelajaran di kelas, tetapi bukan ntuk menguji teori (Tegeh \& Kirna, 2013).

Seiring dengan perubahan jaman ke era 4.0, penelitian dan pengembangan terhadap media pembelajaran interaktif banyak dilakukan. Salah satunya dilakukan oleh (Sari et al., 2019) dengan hasil penelitiannya terkait buku ajar elektronik interaktif (BAEI) berbantuan Google Slide dan Quizziz. Pengembangan ini menggunakan model ADDIE yang menunjukkan bahwa bahan ajar interaktif tersebut mempunyai kualitas yang sangat baik. Selain itu, berdasarkan penelitian yang dilakukan oleh (Purnamasari et al., 2019) mengenai pengembangan media pembelajaran berbasis Google Slide dengan menggunakan model pengembangan ADDIE yang menghasilkan bahan ajar yang dikembangkan mempunyai kualitas yang cukup baik.

Salah satu model pengembangan yaitu model ADDIE yang merupakan suatu model untuk memecahkan masalah dalam pembelajaran yang menyesuaikan dengan karakteristik peserta didik (Winarni, 2018). ADDIE terdiri dari lima tahapan yaitu analysis, design, development, implementation dan evaluation. Pengembangan berfungsi untuk menjembatani antara penelitian dan praktik (Tegeh \& Kirna, 2013). Sedangkan model pembelajaran dapat diartikan sebagai suatu tindak lanjut dari penerapan suatu metode atau pendekatan pembelajaran (Trisiana \& Wartoyo, 2016). Dari latar belakang tersebut, penelitian ini menggunakan model ADDIE sebagai pengembangan media pembelajaran interaktif berbasis Google Slide yang merupakan aplikasi Google dengan fitur interaktif untuk melakukan presentasi. Dari beberapa hasil penelitian mengenai Google Slide, pembelajaran hanya dilakukan pada jenjang sekolah menengah sedangkan pada jenjang sekolah dasar masih belum dilakukan penelitian secara mendalam, sehingga penelitian ini bertujuan untuk mengetahui kualitas dan kelayakan media pembelajaran interaktif berbasis Google Slide pada materi pecahan sederhana di kelas III SD. Keunikan pada penelitian ini yaitu memiliki penjelasan lebih lengkap dan bukan hanya menggunakan tulisan, yaitu disertakan juga video pembelajaran di dalamnya, dan memuat beberapa soal interaktif sehingga siswa tidak bosan pada saat menggunakan media ini dan konsep materi pun dapat divisualisasikan dengan lebih jelas.

Berdasarkan hasil wawancara dengan beberapa pendidik di SDS Muhammadiyah 4 Jakarta terdapat beberapa kesulitan dalam pembelajaran daring terutama pada saat menyampaikan materi pelajaran sehingga dibutuhkan suatu media yang efektif dalam pembelajaran. Lebih lanjutnya berdasarkan hasil observasi yang dilakukan peneliti, di SDS Muhammadiyah 4 Jakarta belum menerapkan media pembelajaran berbasis Google Slide. Oleh karena itu, dalam penelitian ini dikembangkan desain pembelajaran yang bertujuan untuk mengetahui kualitas dan kelayakan media pembelajaran interaktif berbasis Google Slide pada materi pecahan sederhana di kelas III SD. Keunikan pada penelitian ini yaitu memiliki penjelasan lebih lengkap dan bukan hanya menggunakan tulisan, yaitu disertakan juga video pembelajaran di dalamnya, dan memuat beberapa soal interaktif sehingga siswa tidak bosan pada saat menggunakan media ini dan konsep materi pun dapat divisualisasikan dengan lebih jelas.

\section{METODE}

Penelitian dilaksanakan di SDS Muhammadiyah 4 Jakarta, Jl. Dewi Sartika No. 36 A Cawang, Kramat Jati, Jakarta Timur. Penelitian dilakukan selama 6 (enam) sejak bulan Januari 2021 sampai dengan bulan Juni 2021. Sampel pada penelitian ini adalah siswa kelas III SDS Muhammadiyah 4 Jakarta. Penelitian ini menggunakan metode penelitian dan pengembangan (research and development).

Model yang digunakan yaitu model ADDIE yang merupakan adaptasi dari model yang dikembangkan oleh Dick dan Carry (Aji, 2016). ADDIE sebagai suatu model untuk memecahkan masalah dalam pembelajaran 
yang menyesuaikan dengan karakteristik peserta didik (Winarni, 2018). ADDIE mempunyai lima langkah utama yaitu sebagai berikut.

Analisis terhadap pengembangan media (Analyze). Tahap ini merupakan telaah dari berbagai literatur jurnal ataupun skripsi yang memiliki keterkaitan dengan tujuan penelitian. Kemudian dikumpulkan informasi dari guru dan peserta didik dengan melakukan observasi pada kegiatan pembelajaran, penggunaan media, dan faktor-faktor yang menyebabkan masalah.

Perancangan media (Design). Tahap ini mempunyai tujuan untuk mempersiapkan rancangan media dengan membuat slide presentasi pada materi pecahan sederhana menggunakan Google Slide. Pada tahap ini dilakukan pemilihan tema dan pembuatan slide presentasi menggunakan Google Slide.

Pengembangan media (Development). Validasi dilakukan setelah media pembelajaran dikembangkan yang dilakukan oleh dua ahli pada aspek materi dan media untuk mengetahui kelayakan media yang dikembangkan. Validasi materi dilakukan terhadap empat aspek yaitu relevansi, keakuratan, konsep dasar materi, dan kesesuaian sajian dengan materi. Sedangkan validasi media berdasarkan tiga aspek yaitu tampilan umum, tampilan khusus, dan penyajian media.

Implementasi (Implementation). Jika dikatakan telah valid oleh ahli selanjutnya diterapkan kepada peserta didik yaitu siswa Kelas III SDS Muhammadiyah 4 Jakarta dan setelah itu disebarkan kuesioner untuk mengetahui bagaimana respon terhadap produk yang dikembangkan yaitu media interaktif berbasis Google Slide.

Evaluasi (Evaluation). Tahap ini adalah tahap untuk melakukan perbaikan akhir apabila terdapat kekurangan setelah diterapkan kepada peserta didik sehingga untuk media selanjutnya akan lebih baik.

Teknik pengumpulan data dengan menggunakan observasi, wawancara dan angket. Penggunaan angket yaitu sebagai angket validasi materi, validasi media, dan angket respon. Observasi dilakukan untuk mengetahui bagaimana kesulitan peserta didik dalam pembelajaran dikelas. Teknik analisis data yang digunakan adalah analisis deskriptif. Perhitungan angket menggunakan skala likert dengan skala 5 yang kemudian diinterpretasikan dengan acuan (Azizah, 2019) yang disajikan pada Tabel 1.

\section{Tabel 1}

Interpretasi hasil skor skala likert

\begin{tabular}{cc}
\hline Kategori Validitas $(\%)$ & Tingkat Validitas \\
\hline $81,0-100,0$ & Sangat layak \\
\hline $61,0-80,9$ & Layak \\
\hline $41,0-60,9$ & Kurang layak \\
\hline $21,0-40,9$ & Tidak layak
\end{tabular}

\section{HASIL DAN PEMBAHASAN}

Hasil dari pengembangan media interaktif pada materi pecahan sederhana ini dikemas dengan bentuk Google Slide. Media pembelajaran interaktif ini menghasilkan penelitian dengan langkah sebagai berikut.

\section{Analisis terhadap pengembangan media (Analyze)}

Pada tahap ini menghasilkan suatu rumusan konsep yaitu. a) Analisis terhadap kebutuhan dan karakteristik yang menyatakan bahwa keterbatasan media dan kurangnya pengembangan media yang digunakan, b) Materi dan soal pada media pembelajaran yang disesuaikan dengan acuan kompetensi inti dan kompetensi dasar kurikulum sekolah, c) Persiapan terhadap alat dan bahan yang digunakan yaitu konsep rancangan slide presentasi, gambar animasi, video maker dan rekaman suara untuk video pembelajaran. 
2444 Pengembangan Media Pembelajaran Interaktif Berbasis Google Slide pada Materi Pecahan Sederhana di Sekolah Dasar - Syifa Jamilah Purnama, Puri Pramudiani

DOI: https://doi.org/10.31004/basicedu.v5i4.1247

\section{Perancangan media (Design)}

Pada tahapan ini, dilakukan rancangan materi menggunakan Google Slide yang dibuat berwarna dan menarik sesuai dengan jenjang peserta didik dengan menambahkan berbagai gambar dan audio. Hasil desain media dengan menggunakan Google Slide secara garis besar yaitu sebagai berikut.

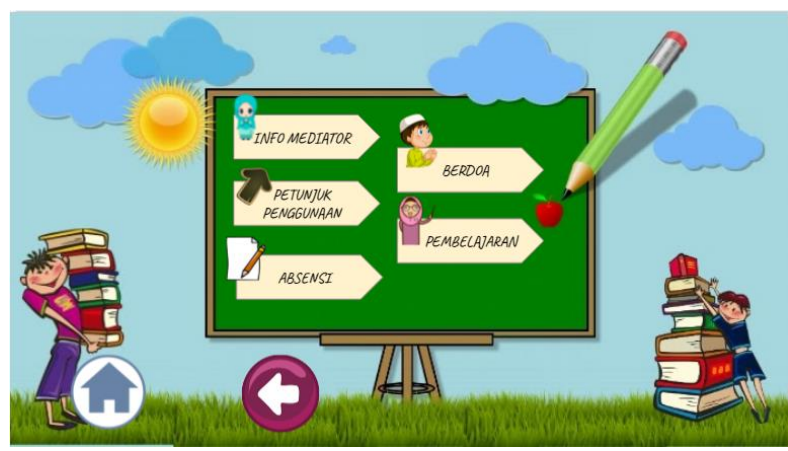

Gambar 1. Pendahuluan Media Pembelajaran

Gambar 1 merupakan desain halaman utama dengan berbagai menu yaitu info, petunjuk penggunaan, absensi, berdoa dan pembelajaran.

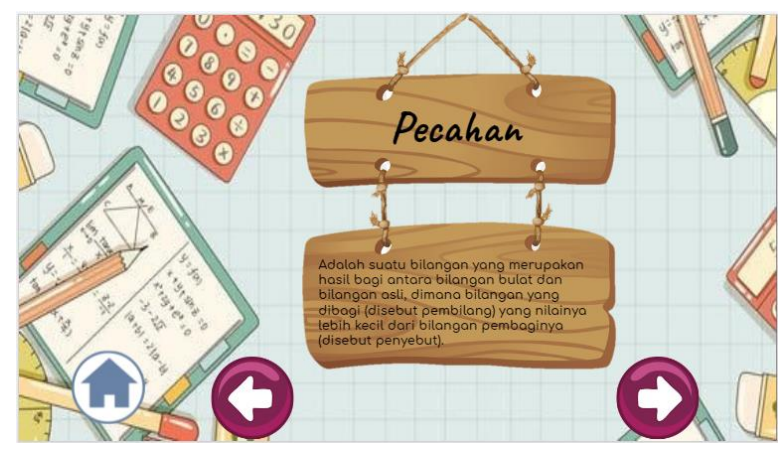

Gambar 2. Materi Media Pembelajaran

Gambar 2 merupakan salah satu halaman materi yang menjelaskan mengenai materi pecahan sederhana. Materi dibuat dengan tampilan yang menarik dan juga menggunakan video pembelajaran.

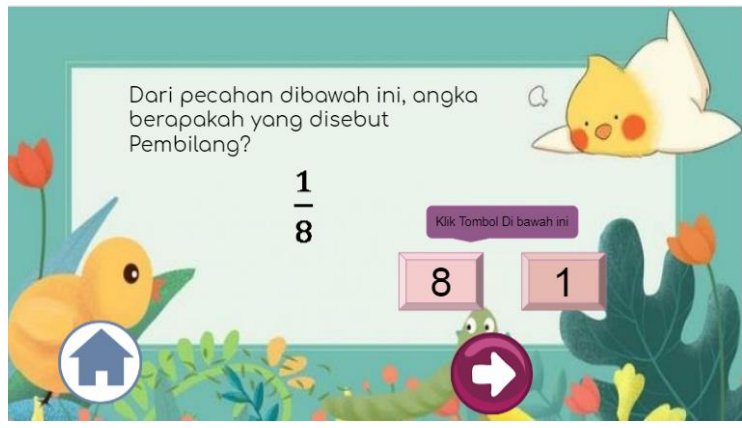

\section{Gambar 3. Latihan Soal Media Pembelajaran}

Gambar 3 merupakan contoh slide yang menampilkan latihan soal yang apabila siswa memilih salah satu jawaban yang tersedia maka akan diketahui apakah benar atau salah dan bagaimana penyelesaiannya. 


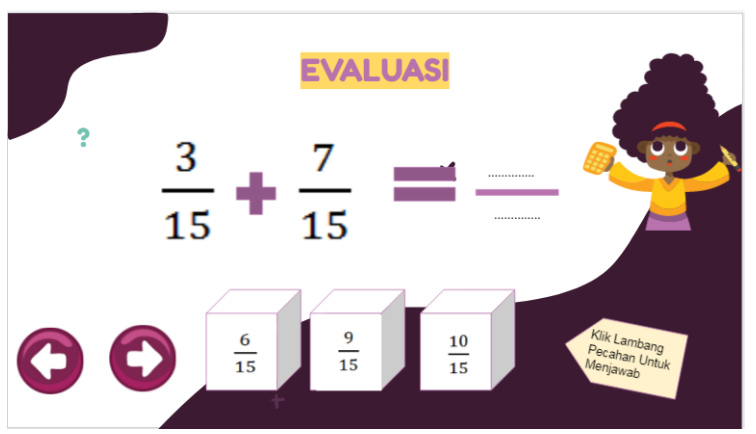

Gambar 4. Evaluasi Media Pembelajaran

Gambar 4. Merupakan slide yang menampilkan evaluasi pembelajaran. Setelah pembelajaran dilakukan selanjutnya dilakukan evaluasi yang mana hasilnya akan diketahui apakah selama pembelajaran siswa menyimak dengan baik atau tidak.

Link pembelajaran dapat diakses di https://bit.ly/googleslide pecahansederhana

\section{Pengembangan media (Development)}

Media pembelajaran interaktif berbasis Google Slide yang dikembangkan ini divalidasi oleh ahli materi dan ahli media. Berdasarkan validasi ahli materi pada seluruh aspek menghasilkan angka sebesar $98 \%$ yang termasuk dalam kategori sangat layak dan hasil validasi ahli media yaitu sebesar $71,1 \%$ yang termasuk dalam kategori layak. Berikut ini disajikan rincian penilaian ahli materi sesuai Tabel 2 dan Tabel 3 penilaian ahli media.

Tabel 2

Hasil penilaian ahli materi

\begin{tabular}{lccc}
\hline Aspek & Perolehan Skor & Rata-rata Presentasi & Kategori \\
\hline Relevansi & 15 & $100 \%$ & Sangat Layak \\
\hline Keakuratan & 19 & $95 \%$ & Sangat Layak \\
\hline $\begin{array}{l}\text { Konsep Dasar Materi } \\
\begin{array}{l}\text { Kesesuaian sajian dengan kebutuhan } \\
\text { yang berpusat pada peserta didik } \\
\text { dalam materi Pecahan Sederhana }\end{array}\end{array}$ & 10 & $100 \%$ & Sangat Layak \\
\hline \multicolumn{1}{c}{ RataanPresentase } & 10 & $100 \%$ & Sangat Layak \\
\hline
\end{tabular}

Tabel 3

Hasil penilaian ahli media

\begin{tabular}{|c|c|c|c|}
\hline Aspek & Perolehan Skor & Rata-rata Presentasi & Kategori \\
\hline Tampilan Umum & 11 & $73,3 \%$ & Layak \\
\hline Tampilah Khusus & 11 & $73,3 \%$ & Layak \\
\hline Penyajian Media & 10 & $66,6 \%$ & Layak \\
\hline \multicolumn{2}{|c|}{ Rataan Presentase } & $71,1 \%$ & Layak \\
\hline
\end{tabular}

\section{Implementasi media (Implementation)}

Penerapan media pembelajaran interaktif berbasis Google Slide pada siswa kelas III SDS Muhammadiyah 4 Jakarta dilakukan pada tahapan implementasi. Setelah dilakukan penerapan selanjutnya dilakukan analisis terkait respon siswa terhadap pembelajaran untuk mengetahui kualitas media yang dikembangkan. Hasil penilaian respon peserta didik yaitu sebesar 4,6 atau 93\% yang termasuk dalam kategori sangat baik yang disajikan pada Gambar 5 sebagai berikut. 
Tabel 4

Hasil angket respon peserta didik

\begin{tabular}{|c|c|c|c|c|c|c|c|c|c|c|c|c|c|c|c|c|}
\hline & & & & & & & & & & & & & & & & \\
\hline No & Nama & kelas & K1 & K2 & K3 & K4 & K5 & K6 & K7 & K8 & K9 & K10 & Jumlah & Rata-Rata & Nilai Max & Presentase \\
\hline 1 & Aicka ganiyya susanto & $3 \mathrm{~A}$ & 5 & 5 & 5 & 4 & 5 & 5 & 4 & 5 & 5 & 5 & 48 & 4,8 & 50 & $96 \%$ \\
\hline 2 & Andi Naysilla Mirsad & $3 \mathrm{~A}$ & 5 & 5 & 5 & 5 & 5 & 4 & 4 & 5 & 5 & 5 & 48 & 4,8 & 50 & $96 \%$ \\
\hline 3 & Aziza Anis abd Aziz & $3 \mathrm{~A}$ & 5 & 5 & 5 & 5 & 5 & 5 & 5 & 5 & 5 & 5 & 50 & 5 & 50 & $100 \%$ \\
\hline 4 & Balski Oufar M Smith & $3 \mathrm{~A}$ & 5 & 5 & 5 & 5 & 5 & 5 & 5 & 5 & 5 & 5 & 50 & 5 & 50 & $100 \%$ \\
\hline 5 & Dzaky almair lutfi & $3 \mathrm{~A}$ & 4 & 4 & 4 & 4 & 4 & 4 & 4 & 4 & 4 & 4 & 40 & 4 & 50 & $80 \%$ \\
\hline 6 & Ellova Al Barra & $3 \mathrm{~A}$ & 3 & 4 & 4 & 4 & 4 & 5 & 5 & 5 & 5 & 5 & 44 & 4,4 & 50 & $88 \%$ \\
\hline 7 & Hafidza Cattleya & $3 \mathrm{~A}$ & 5 & 5 & 5 & 5 & 5 & 5 & 5 & 5 & 5 & 5 & 50 & 5 & 50 & $100 \%$ \\
\hline 8 & Ibrahim Hazel Al Reza & $3 \mathrm{~A}$ & 5 & 5 & 5 & 5 & 5 & 5 & 5 & 5 & 5 & 5 & 50 & 5 & 50 & $100 \%$ \\
\hline 9 & Muhamad Gibran Pratama & $3 \mathrm{~A}$ & 5 & 5 & 5 & 5 & 5 & 5 & 5 & 5 & 5 & 5 & 50 & 5 & 50 & $100 \%$ \\
\hline 10 & M.Rama Zihni Haidar & $3 \mathrm{~A}$ & 5 & 5 & 5 & 5 & 5 & 5 & 5 & 5 & 5 & 5 & 50 & 5 & 50 & $100 \%$ \\
\hline 11 & M. Sabilur Rosyad & $3 \mathrm{~A}$ & 4 & 4 & 4 & 4 & 4 & 4 & 4 & 4 & 4 & 4 & 40 & 4 & 50 & $80 \%$ \\
\hline 12 & Rafisqi bagza saputra & $3 \mathrm{~A}$ & 5 & 5 & 5 & 4 & 4 & 4 & 5 & 4 & 5 & 5 & 46 & 4,6 & 50 & $92 \%$ \\
\hline 13 & Raisa Adelia Pratiwi & $3 \mathrm{~A}$ & 4 & 4 & 3 & 3 & 3 & 3 & 3 & 3 & 4 & 3 & 33 & 3,3 & 50 & $66 \%$ \\
\hline 14 & Syakilla nuril ismail & $3 \mathrm{~A}$ & 4 & 4 & 4 & 3 & 3 & 4 & 4 & 4 & 3 & 4 & 37 & 3,7 & 50 & $74 \%$ \\
\hline 15 & Syam andrew & $3 \mathrm{~A}$ & 5 & 5 & 5 & 5 & 5 & 5 & 5 & 5 & 5 & 5 & 50 & 5 & 50 & $100 \%$ \\
\hline 16 & Teuku Swastika Suranggana Iskandar & $3 \mathrm{~A}$ & 5 & 5 & 5 & 5 & 5 & 5 & 5 & 5 & 5 & 5 & 50 & 5 & 50 & $100 \%$ \\
\hline 17 & Windiyan Shafitri & $3 \mathrm{~A}$ & 5 & 5 & 5 & 5 & 5 & 5 & 5 & 5 & 5 & 5 & 50 & 5 & 50 & $100 \%$ \\
\hline 18 & Zhafira aulia putri narziana & $3 \mathrm{~A}$ & 5 & 5 & 5 & 5 & 5 & 5 & 5 & 5 & 5 & 5 & 50 & 5 & 50 & $100 \%$ \\
\hline 19 & M. Rizki Imam Ibrahim & $3 \mathrm{~A}$ & 5 & 5 & 5 & 5 & 4 & 3 & 5 & 5 & 5 & 5 & 47 & 4,7 & 50 & $94 \%$ \\
\hline & & & & & & & & & & & & & & 4,6 & & $93 \%$ \\
\hline
\end{tabular}

\section{Evaluasi (Evaluation)}

Tahap yang terakhir merupakan evaluasi terhadap penerapan media pembelajaran dan hasil angket yang diberikan kepada peserta didik. Apabila terdapat kekurangan selanjutnya akan dilakukan perbaikan supaya kedepannya media yang dikembangkan akan menjadi lebih baik lagi.

Pengembangan media pembelajaran interaktif berbasis Google Slide pada materi Pecahan Sederhana terdiri dari empat kerangka utama yaitu pendahuluan, materi, latihan soal dan evaluasi. Penyajian materi pada Pecahan Sederhana Tema 5 dimana materi dilengkapi video yang berkaitan dengan kejadian sehari-hari sebagai pendahuluan pembelajaran. Sajian dalam uraian materi menggunakan animasi berupa permasalahan yang realistik sehingga pembelajaran menggunakan media ini bersifat kontekstual. Menurut Sadiman dalam Rachmadyanti \& Gunansyah (2020) pembuatan media mengharuskan bersifat kontekstual agar menumbuhkan aktivitas dan tujuan pembelajaran.

Pada media berbasis Google Slide ini terdapat latihan soal dan evaluasi interaktif seperti yang disajikan pada Gambar 4 dan Gambar 5. Soal yang disajikan dalam media interaktif mempunyai perbedaan dibandingkan dengan buku cetak. Ketika peserta didik melakukan pengerjaan soal-soal tersebut, maka akan langsung dapat memilih jawaban dan mengetahui jawaban benar atau salah serta nilai akhir yang didapatkan oleh peserta didik. Penggunaan audio juga dilengkapi dalam media ini untuk membuat peserta didik menjadi lebih semangat dan mendapatkan motivasi untuk belajar.

Dalam mengembangkan media pembelajaran interaktif berbasis Google Slide ini, validasi dilakukan oleh ahli materi dan ahli media. Hal ini mempunyai tujuan untuk mengetahui kelayakan media pembelajaran yang akan digunakan untuk media peserta didik dalam memahami konsep materi Pecahan Sederhana. Seluruh aspek materi yang dinilai oleh validator menghasilkan nilai sebesar $98 \%$ yang mempunyai kategori sangat layak dan aspek media menghasilkan nilai sebesar $71,1 \%$ yang mempunyai kategori layak.

Kedua ahli memberikan beberapa saran untuk melakukan revisi sebelum mengimplementasikan kepada peserta didik. Selanjutnya media ini diterapkan pada pembelajaran Pecahan Sederhana di Kelas III SDS Muhammadiyah 4 Jakarta dan setelah pembelajaran berlangsung peserta didik di berikan angket respon untuk 
mengetahui penilaian terhadap media yang menghasilkan nilai respon sebesar 4,6 atau 93\% yang termasuk dalam kategori sangat layak. Beberapa komentar dan saran yang diberikan oleh orang tua peserta didik menunjukkan bahwa media yang digunakan sangat membantu peserta didik dan memiliki motivasi yang lebih terhadap pembelajaran. Hal ini sesuai dengan hasil penelitian (Arda et al., 2015) yang menyatakan jika pembelajaran dengan menggunakan media dapat menimbulkan motivasi untuk belajar.

Penelitian ini juga sejalan dengan hasil penelitian (Nata \& Putra, 2021) yang menyatakan bahwa media pembelajaran interaktif sangat baik digunakan dalam kegiatan pembelajaran karena menarik minat peserta didik. Media pembelajaran menggunakan slide presentasi ini juga memuat berbagai animasi yang sesuai dengan tema sehingga siswa dapat terlibat secara konsep materi. Hasil ini juga sejalan dengan penelitian yang dilakukan oleh (Damayanti \& Qohar, 2019) yang menyatakan bahwa media pembelajaran interaktif dengan power point dapat membantu siswa dalam memahami konsep.

Secara umum, faktor yang mendukung media pembelajaran yang dikembangkan adalah kerjasama yang baik antara guru dan peserta didik sehingga membuat peserta didik terlibat secara aktif dalam proses pembelajaran dan penggunaan animasi pada slide membuat peserta didik tertarik dan termotivasi untuk belajar. Namun, media ini juga mempunyai keterbatasan yaitu memerlukan akses internet dan akun Google untuk dapat menggunakan medianya, lalu belum memiliki fitur yang dapat mengunci slide, sehingga ketika slide diklik di luar tombol interaktif maka akan berpindah pada slide selanjutnya. Dengan demikian pembuatan media ini harus memiliki susunan yang rapi sehingga tidak terjadi kendala yang sulit pada saat menggunakan media.

\section{KESIMPULAN}

Dari hasil penelitian dan pengembangan dapat disimpulkan bahwa media pembelajaran interaktif berbasis Google Slide yang dikembangkan telah layak dan dapat digunakan sebagai media pembelajaran guna meningkatkan pemahaman konsep peserta didik terutama terhadap materi Pecahan Sederhana. Media pembelajaran interaktif yang dikembangkan ini masih terbatas pada materi Pecahan Sederhana. Dengan keterbatasan ini, peneliti menyarankan untuk melakukan pengembangan lebih lanjut di berbagai materi pelajaran lainnya dan dapat dilakukan dengan menggunakan software atau platform lainnya sehingga pemahaman peserta didik terhadap materi dapat ditingkatkan lagi.

\section{UCAPAN TERIMA KASIH}

Penulis mengucapkan terima kasih kepada Allah SWT yang telah memberikan kekuatan dan kesehatan, kepada orang tua, keluarga dan teman-teman yang telah mendukung untuk kesuksesan penelitian ini, serta kepada siswa-siswi dan guru-guru SDS Muhammadiyah 4 Jakarta yang telah bersedia menjadi target penelitian ini.

\section{DAFTAR PUSTAKA}

Aji, W. N. (2016). Model Pembalajaran Dick and Carrey dalam Pembelajaran Bahasa dan Sastra Indonesia. Kajian Linguistik Dan Sastra, 1(2), 119-126.

Anshori, F. Al, \& Syam, S. (2018). Pengaruh Penggunaan Aplikasi Google Slide Terhadap Minat Bertanya Mahasiswa Pendidikan Biologi. Jurnal Pendidikan Biologi, 3(2).

Arda, Saehana, S., \& Darsikin. (2015). Pengembangan Media Pembelajaran Interaktif Berbasis Komputer untuk Siswa SMP Kelas VIII. Jurnal Mitra Sains, 3(1), 69-77.

Arindiono, R., Arindiono, R. J., \& Ramadhani, N. (2013). Perancangan Media Pembelajaran Interaktif Matematika untuk siswa kelas 5 SD. Jurnal Sains Dan Seni ITS, 2(1), 28-32.

Azizah, Z. F. (2019). Instrumen Angket Validasi Pengembangan Media Fung-Cube Pada Pembelajaran Fungi Untuk Siswa SMA. Journal of Chemical Information and Modeling, 53(9), 1689-1699. 
2448 Pengembangan Media Pembelajaran Interaktif Berbasis Google Slide pada Materi Pecahan Sederhana di Sekolah Dasar - Syifa Jamilah Purnama, Puri Pramudiani

DOI: https://doi.org/10.31004/basicedu.v5i4.1247

Budiman, H. (2016). Penggunaan Media Visual dalam Proses Pembelajaran. Al Tadzkiyyah: Jurnal Pendidikan Islam, 7(1).

Damayanti, P. A., \& Qohar, A. (2019). Pengembangan Media Pembelajaran Matematika Interaktif Berbasis Powerpoint pada Materi Kerucut. Kreano, Jurnal Matematika Kreatif-Inovatif, 10(2), 119-124.

Dwijayani, N. M. (2019). Development of circle learning media to improve student learning outcomes. Journal of Physics: Conference Series, 1321(2), 171-187. https://doi.org/10.1088/1742-6596/1321/2/022099

Fitra, J., \& Maksum, H. (2021). Efektivitas Media Pembelajaran Interaktif dengan Aplikasi Powntoon pada Mata Pelajaran Bimbingan TIK. Jurnal Pedagogi Dan Pembelajaran, 4(1), 1-13.

Ihsana, E. K. (2017). Belajar dan Pembelajara: Konsep Dasar, Metode, dan Aplikasi Nilai-nilai Spiritualitas dalam Proses Pembelajaran. Pustaka Pelajar.

Jannah et al. (2021). Jurnal basicedu. Jurnal Basicedu, 5(2), 1060-1066.

Nata, I. K. W., \& Putra, D. K. N. S. (2021). Pengembangan Media Pembelajaran Multimedia Interaktif Pada Muatan IPA Kelas V Sekolah Dasar. Jurnal Ilmiah Pendidikan Dan Pengembangan, 5(2).

Purnamasari, S., Heryawan, A., \& Ardie, R. (2019). Pengembangan Model Media Pembelajaran Berbasis Google Slide Pada Mata Pelajaran IPS Di SMP. Jurnal Teknologi Pendidikan Dan Pembelajaran, 6(1).

Rachmadyanti, P., \& Gunansyah, G. (2020). Pengembangan Ebook untuk Mata Kuliah Konsep Dasar IPS Lanjut bagi Mahasiswa PGSD UNESA. Jurnal Riset Pedagogik, 4(1), 83-93.

Rahmah, N. (2013). Hakikat Pendidikan Matematika. Jurnal Pendidikan Matematika Dan Ilmu Pengetahuan Alam, 1(2), 1-10.

Sari, A. O., Kusuma, G. C., \& Anggraini, D. (2019). Google Slide dan Quizizz dalam Pengembangan Buku Ajar Elektronik Interaktif (BAEI) Matematika. Jurnal Ilmiah Pendidikan Matematika, Ilmu Matematika Dan Matematika Terapan, 9(2).

Setiawan, A. P., Masruri, L., Trastianingrum, S. A. P., \& Purwandari, E. (2021). Efek Metode Pembelajaran Daring (Pembelajaran Jarak Jauh) Akibat Covid-19: Perspektif Pelajar dan Mahasiswa. Proyeksi, 16(1), 83-91.

Tegeh, I. M., \& Kirna, I. M. (2013). Pengembangan Bahan Ajar Metode Penelitian Pendidikan Dengan Addie Model. Jurnal Ika, 11(1), 16.

Trisiana, A., \& Wartoyo. (2016). Desain Pengembangan Model Pembelajaran Pendidikan Kewarganegaraan melalui Addie Model untuk Meningkatkan Karakter Mahasiswa di Universitas Slamet Riyadi Surakarta. PKn Progresif, 11(1), 312-330.

Winarni, E. W. (2018). Teori dan Praktik Penelitian Kuantitatif Kualitatif (B. Aksara (ed.)). 